\title{
FORMATION OF THE MECHANICAL PROPERTIES AND FRACTURE RESISTANCE CHARACTERISTICS OF SANDWICH COMPOSITES BASED ON THE 09G2S STEEL AND THE EP678 HIGH-STRENGTH STEEL OF VARIOUS DISPERSION
}

\author{
S. V. Gladkovsky ${ }^{1 *}$, S. V. Kuteneva ${ }^{1}$, I. S. Kamantsev ${ }^{1}$, \\ R. M. Galeev², D. A. Dvoynikov ${ }^{1}$ \\ ${ }^{1}$ Institute of Engineering Science, Ural Branch of the Russian Academy of Sciences, \\ 34 Komsomolskaya St., Ekaterinburg, Russian Federation \\ ${ }^{2}$ Institute for Metals Superplasticity Problems, Russian Academy of Sciences, \\ 39 Stepana Khalturina St., Ufa, Russian Federation \\ *Corresponding author. E-mail: gsv@imach.uran.ru \\ Address for correspondence: ul. Komsomolskaya, 34, 620049, Ekaterinburg, Russian Federation \\ Tel.: +7 (343) 36234 48; fax: +7 (343) 3745330
}

The structure, mechanical properties and impact strength of 5-layered composites based on maraging and low-alloy mild steels are investigated. The effect of subsequent heat treatment on the microstructure and mechanical properties of layered composites is studied. The contribution of the presence of the initial ultrafine-grained microstructure of maraging steel to the formation of the mechanical properties of explosion-welded and thermally strengthened layered composites is evaluated.

Keywords: layered composite, explosion welding, low-alloy mild steel, maraging steel, microstructure, mechanical properties, brittle fracture resistance characteristics.

DOI: $10.17804 / 2410-9908.2017 .6 .071-090$

\section{References}

1. Chawla N., Chawla K.N. Metal matrix Composites, 2nd ed., New York, Springer Science+Business Media, 2013, 370 p. DOI: https://doi.org/10.1007/978-0-387-74365-3_6

2. Kobelev A.G., Lysak V.I., Chernyshev V.N., Bykov A.A., Vostrikov V.P. Proizvodstvo Metallicheskikh Sloistykh Kompozitsionnykh Materialov [Production of Laminated Metal Composite Materials]. Moscow, Intermet Inzhiniring Publ., 2002, 496p. (In Russian).

3. Smirnov S.V., Veretennikova I.A. Comparative Evaluation of Metal Damage on the Free Lateral Surface of Single-Layer and Three-Layer Strips under Rolling. Diagnostics, Resource and Mechanics of materials and structures, 2015, no. 4, pp. 6-15. Available at: http://dreamjournal.org/DREAM_Issue_4_2015_Smirnov_S.V._et_al._006_017.pdf

4. Kolesnikov A.G., Plokhikh A.I. A study of special features of formation of submicro- and nanosize structure in multilayer materials by the method of hot rolling. Metal Science and Heat Treatment, 2010, vol. 52, iss. 5-6, pp. 44-49. DOI: 10.1007/s11041-010-9266-x

5. Trykov Yu.P., Gurevich L.M., Shmorgunov V.G. Sloistye Kompozity na Osnove Alyuminiya i Ego Splavov [Laminated Composites Based on Aluminum and Its Alloys]. Moscow, Metallurgizdat Publ., 2004, 230 p. (In Russian).

6. Lozhkin V.S., Lozhkina E.A., Mali V.I., Esikov M.A. Structure and mechanical properties of multilayered composite material, formed by explosive welding of steel 12X18H10T and steel H18K9M5T thin plates. Obrabotka metallov (tekhnologiya, oborudovanie, instrumenty, 2014, no. 3 (64), pp. 28-36. (In Russian).

7. Maltseva L.A., Tyushlyaeva D.S., Maltseva T.V., Pastukhov M.V., Lozhkin N.N., Inyakin D.V., Marshuk L.A. Laminated Metal Composite Materials Produced by Explosion Welding: Structure, Properties, Structural Features of the Transition Zone. Deformatsiya I Razrushenie Materialov, 2013, no. 4, pp. 19-26. (In Russian). 
8. Embury J.D., Petch N.J., Wraith A.E., Wright E.S. The fracture of mild steel laminates. Transactions of the Metallurgical Society of AIME, 1967, vol. 239, pp. 114-118.

9. Botvina R.L. Razrushenie. Kinetika, Mekhanizmy, Obshchie Zakonomernosti. [Fracture. Kinetics, General Mechanisms]. Moscow, Nauka Publ., 2008, 334 p. (In Russian).

10. Landau L.D. On the problem of turbulence. Doklady AN SSSR, 1944, vol. 44, no. 8, pp. 339-342. (In Russian).

11. Cowan G.R., Bergmann O.R., Holtzman A.H. Mechanism of bond zone wave formation in explosion-clad metals. Metallurgical and Materials Transactions B, 1971, vol. 2, no. 11, pp. 3145-3155.

12. Deribas A.A. Fizika Uprochneniya i Svarka Vzryvom [Physics of Hardening and Explosion Welding]. Novosibirsk, Nauka Publ., 1980, 220 p. (In Russian).

13. Mali V.I., Bataev I.A., Bataev A.A., Pavlyukova D.V., Prikhodko E.A., Esikov M.A. Geometric transformations of sheet steel billets in explosion welding of multiple sandwiches. Fizicheskaya mezomekhanika, 2011, vol. 6, no. 14, pp. 117-124. (In Russian).

14. Lysak V.I., Kuzmin S.V. Producing composite materials by explosive welding. Vestnik Yuzhnogo Nauchnogo Tsentra, 2013, vol. 9, pp. 64-69. (In Russian).

15. Perkas M.D. Vysokoprochnoye Martensitno-Stareyushchie Stali [High-Strength Maraging Steels]. Moscow, Metallurgiya Publ., 1970, 224 p. (In Russian).

16. Gladkovsky S.V., Potapov A.I., Lepikhin S.V. Studying the deformation resistance of EP679 maraging steel Investigation EP679. Diagnostics, Resource and Mechanics of Materials and Structures. 2015, no. 4, pp. 16-26. Available at: http://dream-journal.org/ /DREAM_Issue_4_2015_Smirnov_S.V._et_al._006_017.pdf

17. Sedykh V.S., Sonnov A.P., Shmorgunov V.G. Determination of local strain under explosion welding. Izvestiya Vuzov. Chernaya Metallurgiya, 1984, no. 11, p. 136. (In Russian).

18. Martin J.W. Mikromekhanizmy Dispersionnogo Tverdeniya Splavov [Micromechanisms in Particle-Hardened Alloys]. Moscow, Metallurgiya Publ., 1983, 167 p. (Russian translation). 
Подана в журнал: 23.11 .2017

УДК 621.771.016.2-419.5.669.14:669.71:620.17

DOI: $10.17804 / 2410-9908.2017 .6 .071-090$

\title{
ФОРМИРОВАНИЕ КОМПЛЕКСА МЕХАНИЧЕСКИХ СВОЙСТВ И ХАРАКТЕРИСТИК СОПРОТИВЛЕНИЯ РАЗРУШЕНИЮ \\ СЭНДВИЧ-КОМПОЗИТОВ НА ОСНОВЕ СТАЛИ О9Г2С И ВЫСОКОПРОЧНОЙ СТАЛИ ЭПб78 РАЗЛИЧНОЙ ДИСПЕРСНОСТИ
}

\author{
С. В. Гладковский ${ }^{1 *}$, С. В. Кутенева ${ }^{1}$, И. С. Каманцев ${ }^{1}$, \\ Р. М. Галеев ${ }^{2}$, Д. А. Двойников ${ }^{1}$ \\ ${ }^{1}$ Федеральное учреждение науки Институт машиноведения Уральского отделения Российской академии наук, \\ ул. Комсомольская, 34, Екатеринбург, Российская Федерация \\ ${ }^{2}$ Институт проблем сверхпластичности металлов Российской академии наук, \\ ул. Халтурина, 39, Уфа, Российская Федерация \\ *Ответственный автор. Электронная почта: gsv@imach.uran.ru \\ Адрес для переписки: ул. Комсомольская, 34, Екатеринбург, Российская Федерация \\ Тел.: +7 (343) 362-42-17, факс: +7 (343) 374-53-30
}

Исследована структура, механические свойства, характеристики ударной вязкости, динамической и циклической трещиностойкости полученных сваркой взрывом 5-слойных композитов на основе 09Г2С и высокопрочной мартенситно-стареющей стали ЭП678. Определена роль дисперсности структуры прослоек мартенситно-стареющей стали в формировании конечного комплекса механических характеристик слоистых материалов. Изучено влияние последующей после сварки взрывом термической обработки на изменение структуры и механических свойств сэндвич-композитов.

Ключевые слова: слоистый композит, сварка взрывом, низкоуглеродистая низколегированная сталь, мартенситно-стареющая сталь, микроструктура, механические свойства, характеристики сопротивления хрупкому разрушению.

\section{1. Введение}

Все более широкое применение в различных отраслях транспортного и энергетического машиностроения, судостроения и авиакосмической техники находят перспективные слоистые металлические композиты с сэндвич-структурой конструкционного и функционального назначения, относящиеся к общему классу многокомпонентных материалов. Слоистые композиты на металлической основе обладают уникальным сочетанием физикомеханических свойств, а также повышенным сопротивлением хрупкому разрушению в широком температурном диапазоне. Конструкции современных слоистых металлических композиционных материалов (СМКМ) обеспечивают технологическую возможность совмещения высокопрочных и пластичных компонент, что позволяет за счет изменения объемной доли и порядка чередования слоев управлять механическими свойствами многослойного материала $[1,2]$. Однако выбор технологии получения слоистых композитов с прочным соединением слоев из различных по своей природе и свойствам материалов требует тщательного учета ряда параметров процесса их изготовления (температуры, скорости и степени деформации), способности материалов к пластической деформации, взаимной растворимости и типа кристаллического строения составляющих композита [2, 3, 4]. Одной из эффективных технологий изготовления СМКМ со слоями, резко различающимися по составу и уровню механических свойств, на сегодняшний день является сварка взрывом [2]. В качестве дополнительного инструмента управления структурой и свойствами слоистых композитов может 
служить последующая после сварки взрывом термическая обработка, режим которой выбирается с учетом структурных преобразований в каждой составляющей композита. Эффективность использования прослоек высокопрочных мартенситно-стареющих сталей (МСС) в конструкции многослойных композитов различного состава с сэндвич-структурой, в том числе с использованием последующей термопластической обработки, представлена в работах $[5,6,7]$. В то же время влияние дисперсности высокопрочных прослоек мартенситностареющих сталей и эволюции структуры составляющих композита при последующей термической обработке на комплекс механических свойств и характеристик сопротивления хрупкому разрушению изучено недостаточно. В связи с этим в работе методами оптической и электронной микроскопии исследовано строение межслойных границ и микроструктура отдельных слоев, определен комплекс стандартных механических свойств и характеристик трещиностойкости при различных условиях нагружения СМКМ на основе сталей 09Г2С и ЭП678 с различной дисперсностью структуры в состоянии непосредственно после сварки взрывом, а также после дополнительной термической обработки.

\section{2. Материалы и методы исследования}

В качестве исходных составляющих 5-слойных композитов использовались три пластины конструкционной низкоуглеродистой стали 09Г2С толщиной 2 мм и две пластины мартенситно-стареющей стали ЭП678 толщиной 1 мм. Объемная доля наиболее прочной стали ЭП678 в слоистых композитах составляла 25 \%. Выбор материалов обусловлен низким содержанием углерода в обеих сталях 09Г2С и ЭП678, что обеспечивает им хорошую способность к деформационной обработке в широком диапазоне температур, а также возможность реализации такой термической обработки композита, при которой слои из мартенситно-стареющей стали максимально упрочняются, а слои из низкоуглеродистой низколегированной стали сохраняют свою исходную пластичность. Химический состав сталей определяли на оптическом эмиссионном спектрометре SPECTROMAXx (табл. 1).

Таблица 1 - Химический состав исследуемых сталей

\begin{tabular}{|c|c|c|c|c|c|c|c|c|c|c|c|c|}
\hline \multirow{2}{*}{ Сталь } & \multicolumn{12}{|c|}{ Содержание элементов, \% (мас.) } \\
\hline & $\mathrm{C}$ & $\mathrm{Si}$ & $\mathrm{Mn}$ & $\mathrm{Cr}$ & $\mathrm{Ni}$ & Mo & $\mathrm{Al}$ & $\mathrm{Ti}$ & $\mathrm{Nb}$ & $\mathrm{Cu}$ & $\mathrm{S}$ & $\mathrm{P}$ \\
\hline & 026 & 16 & 0,082 & 10,65 & 9 & 1,97 & 0 , & 0,9 & 0,093 & 0,1 & 0,004 & 0,004 \\
\hline $09 \Gamma 2 \mathrm{C}$ & 131 &, 68 & 1,11 & 0,068 & 0,065 & 0,011 & 0,037 & - & - & 0,122 & 0,011 & 0,022 \\
\hline
\end{tabular}

В многослойном пакете перед сваркой взрывом сталь 09Г2С находилась в нормализованном состоянии, а мартенситно-стареющая сталь ЭП678 - в закаленном с обычной мелкозернистой (М3) структурой или после термопластической обработки на ультрамелкозернистую (УМЗ) структуру. Листовые заготовки толщиной 1 мм из стали ЭП678 с УМЗ структурой были получены в ИПСМ РАН (г. Уфа) путем комбинированной деформационной обработки, включающей шестикратную всестороннюю изотермическую ковку (ВИК) на гидравлическом прессе ПА2638 в интервале температур 850-700 ${ }^{\circ} \mathrm{C}$ со скоростью деформации $10^{-3}-5 \times 10^{-3} \cdot c^{-1}$ и последующую многопроходную теплую пакетную прокатку на стане ДУО-300 при температуре $700{ }^{\circ} \mathrm{C}$. Исходные размеры заготовки стали ЭП678 составляли $95 \times 85 \times 50$ мм, а на заключительном переходе ВИК ей была придана форма плиты толщиной 24 мM.

Накопленная истинная деформация материала в результате ВИК достигла величины $e \approx 12$, суммарная величина истинной деформации при прокатке, рассчитанная как $e_{h}=\ln \left(h_{0} / h_{1}\right)$, составила $e \approx 3$. При этом суммарная величина степени обжатия заготовок при прокатке составила $\varepsilon \approx 0,95$ (95\%). Таким образом, общая величина истинной накопленной 
деформации после полного цикла обработки исходной заготовки, включающей ВИК и теплую прокатку, составила $e \approx 15$.

Использованные для проведения исследований два типа 5-слойных СМКМ, включающих слои стали 09Г2С и стали ЭП678 с УМЗ (композит 1) и МЗ структурой (композит 2), были получены по технологии сварки взрывом. Изучение строения границ раздела и микроструктуры слоев в композитах проводили с применением традиционных методов металлографии на оптическом микроскопе NEOPHOT 21, а также методом ориентационно-фазового контраста на растровом электронном микроскопе TESCAN MIRA 3 LMH. Распределение легирующих элементов на границе соединения слоев исследовали методом микрорентгеноспектрального анализа на растровом электронном микроскопе TESCAN VEGA II XMU, оснащенного системой энергодисперсионного микроанализа INCA Energy 450. Измерения микротвердости по поперечному сечению композитов выполняли на микротвердомере Shimadzu HMV-G при нагрузке 0,05 кг с шагом 50-150 мкм.

Механические свойства композитов определяли при испытаниях плоских образцов на одноосное растяжение по ГОСТ 1497-84 с применением сергидравлической универсальной испытательной машины INSTRON 8801.

Ударные испытания образцов композиционных материалов проводились на инструментированном маятниковом копре Tinius Olsen IT542M при температурах $20{ }^{\circ} \mathrm{C}$ и $-60{ }^{\circ} \mathrm{C}$ на образцах типа 12 по ГОСТ 9454 с V-образным надрезом, выполненным перпендикулярно плоскости сопряжения пластин по тормозящему движение трещины типу («crack-arrester» [8]). Разделение общей работы разрушения ударного образца $\left(A=A_{3}+A_{P}\right)$ на ее составляющие работу зарождения трещины $A_{3}$ и работу распространения трещин $A_{P}$ осуществляли на основе анализа экспериментальных диаграмм ударного нагружения в соответствии с рекомендациями ГОСТ 22848-77. Параметр динамической трещиностойкости $\left(J_{i d}\right)$ рассчитывался по формуле, приведенной в работе [9]:

$$
J_{i d}=\frac{2 A_{3}}{B(W-a)},
$$

где $A_{3}$ - работа зарождения трещины; $B$ - ширина образца; $W$ - высота образца; $a$ - длина концентратора напряжений (надреза).

Значения показателей прочности, пластичности и характеристик ударной вязкости усредняли по результатам испытаний трех идентичных образцов. Разброс экспериментальных значений механических характеристик не превышал 5 \%. Циклические испытания композиционных материалов проводили по схеме трехточечного изгиба на призматических образцах размером $8 \times 5 \times 55$ мм с V-образным надрезом (тип 4 по ГОСТ $25.506-85$ ) на резонансной испытательной машине MIKROTRON (Rumul) c максимальным усилием цикла $F=2,0$ кН при частоте 100 Гц и коэффициенте асимметрии цикла $R=0,1$. По результатам испытаний в соответствии с рекомендациями РД 50-345-82 строились кинетические диаграммы усталостного разрушения (КДУР) в координатах «скорость роста усталостной трещины размах коэффициента интенсивности напряжений».

Получение композитов сваркой взрывом проводилось в Институте гидродинамики им. М.А. Лаврентьева СО РАН (г. Новосибирск) под руководством в.н.с., к.ф.-м.н. В.И. Мали.

\section{3. Результаты и обсуждение}

Как показал проведенный в продольном сечении образца анализ макроструктуры неразъемного соединения, при сварке взрывом в 5-слойных композитах «09Г2С-ЭП678» формируются как волнообразные, так и прямолинейные границы соединения слоев с разной интенсивностью перемешивания используемых сталей (рис. 1). Волнообразные сварные соединения наблюдаются между первым и вторым, вторым и третьим, а также третьим и четвер- 
тым слоями. Обработка изображения и проведенные расчеты стандартными программными средствами показали, что параметры волн сварного соединения (амплитуда, длина) существенно отличаются по мере чередования слоев в композите. При этом выявленный волнообразный характер строения сварных наиболее четких границ раздела слоев 09Г2С-ЭП678 (граница 1) и ЭП678-09Г2С (граница 4) на основании замеренных параметров волн может быть описан тригонометрической функцией. Проведенные расчеты позволили в первом приближении установить аналитические зависимости формы границ сварных швов 1 и 4, выраженные функциями, представленными в табл. 2.

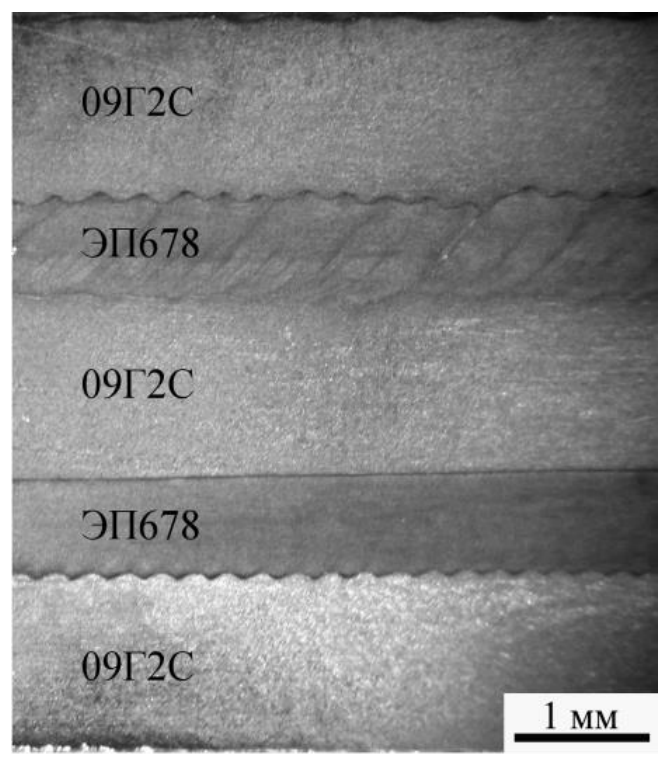

Рис. 1. Макроструктура сварных швов в композите 1 (УМЗ МСС)

Таблица 2 - Параметры и аналитические зависимости сварных швов 5-слойного композита 1 (УМЗ МСС)

\begin{tabular}{|c|c|c|c|c|}
\hline \multirow{2}{*}{$\begin{array}{l}\text { № } \\
\text { П.П. }\end{array}$} & \multicolumn{4}{|c|}{ Продольное сечение 5-СМКМ } \\
\hline & $\begin{array}{c}\text { Граница } \\
\text { материалов }\end{array}$ & $\begin{array}{c}\text { Амплитуда } \\
A, \text { мм }\end{array}$ & $\begin{array}{c}\text { Длина волны } \\
L, \text { мм }\end{array}$ & $\begin{array}{c}\text { Аналитическая } \\
\text { зависимость }\end{array}$ \\
\hline 1 & 09Г2С/ЭП678 & 0,038 & 0,179 & $a=0,038 \sin (2 \pi l / 0,179)$ \\
\hline 2 & ЭП678/09Г2С & - & - & - \\
\hline 3 & 09Г2С/ЭП678 & - & - & - \\
\hline 4 & ЭП678/09Г2С & 0,026 & 0,231 & $a=0,026 \sin (2 \pi l / 0,231)$ \\
\hline
\end{tabular}

Переход от безволнового течения к волновому описывается в рамках теории Л.Д. Ландау [10] о развитии неустойчивости течения вязкой жидкости и определяется несколькими параметрами, одним из которых является число Рейнольдса Re. Критическое значение $\mathrm{Re}$, при котором осуществляется волнообразование, составляет $\operatorname{Re} \geq 10$ [11]. При этом считается $[12,13]$, что форма границы не влияет на качество соединения при сварке взрывом, но граница раздела сложной формы благоприятно сказывается на уровне ударной вязкости композита. Все исследуемые в настоящей работе сварные соединения композитов характеризуются повышенной чистотой границ. На границах отсутствуют неметаллические включения и такие дефекты сварки как поры, непровары и несплошности. Вблизи межслойных границ со стороны 09Г2С наблюдаются зоны локального расплавления (рис. $2 a$ ), строение и расположение которых нерегулярно относительно границы раздела. В ходе исследования сварного шва композита 1 (УМЗ МСС) методом микрорентгеноспектрального анализа была выявлена 
ittp.///ream-journal.or"]

область резкого концентрационного перехода, преобладающая в основном вдоль всей границы сварных швов (рис. 3), тем самым подтверждая скоротечность взрывного процесса, исключающего диффузионные процессы $[12,14]$.

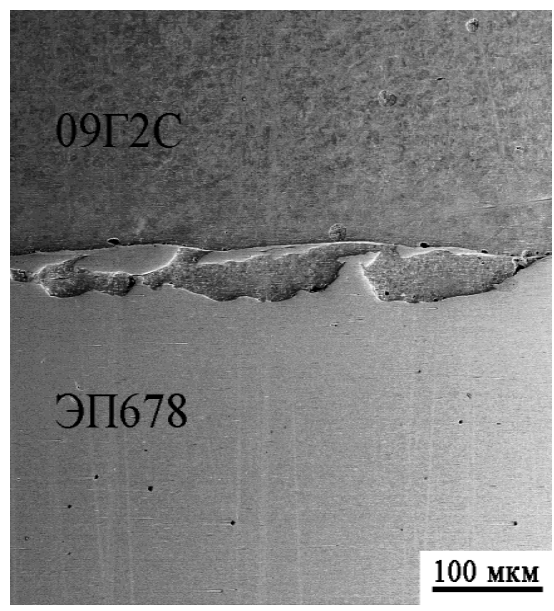

$a$

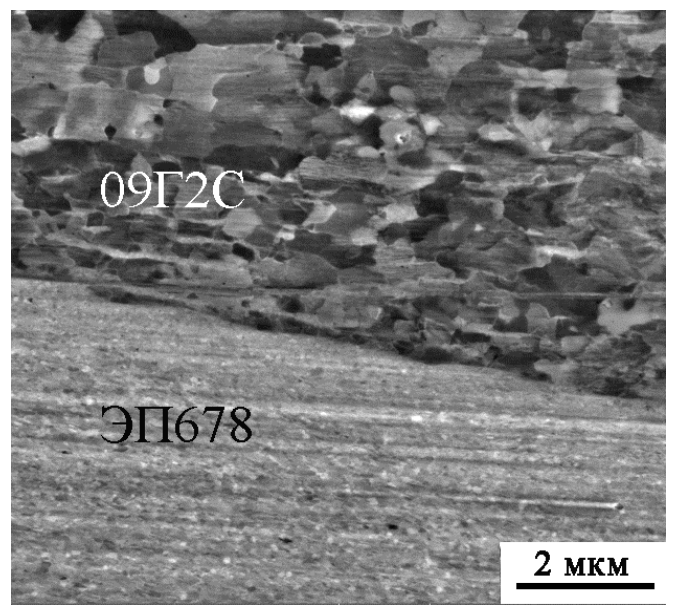

$\sigma$

Рис. 2. Структура композита 1 (УМЗ МСС)

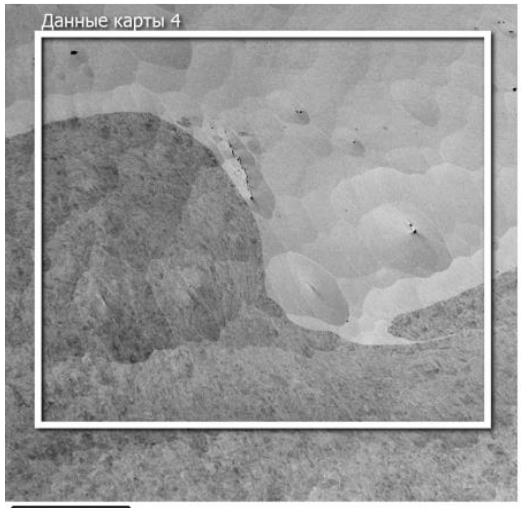

Ni Ka1

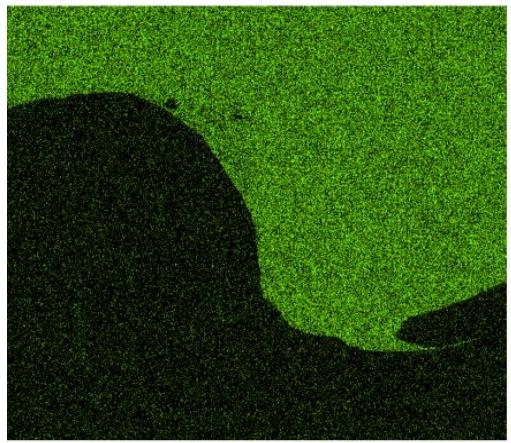

$100 \mu \mathrm{m}$
$\mathrm{Cr} \mathrm{K \alpha 1}$

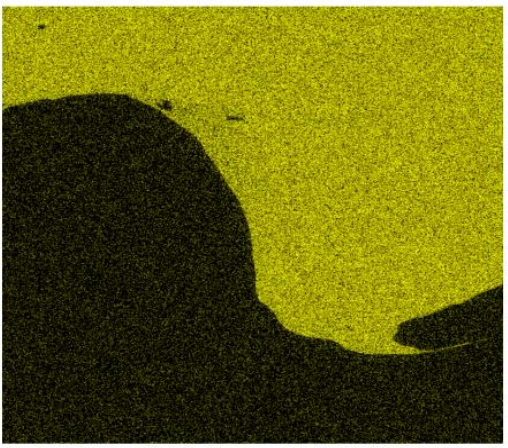

Si Ka1

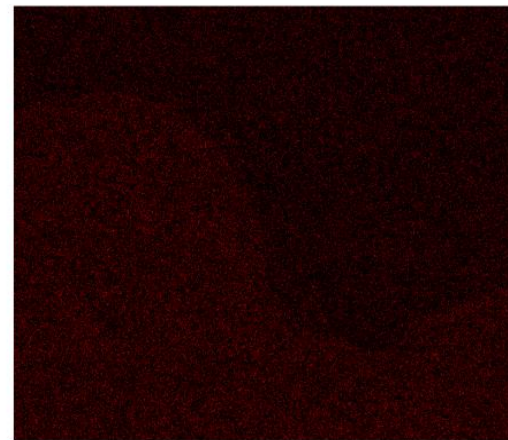

$100 \mu \mathrm{m}$
Mo L $\alpha 1$

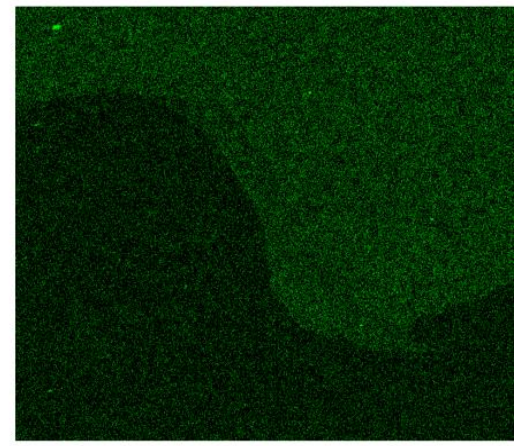

Ti $K \alpha 1$

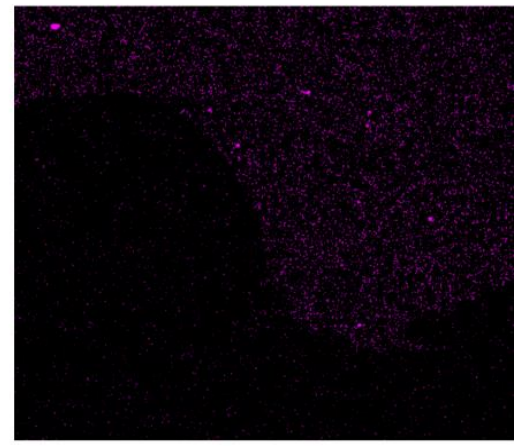

$100 \mu \mathrm{m}$

Рис. 3. Карты распределения элементов на границе сварного шва 5-слойного композита 1 (УМЗ МСС)

Анализ изображений микроструктуры составляющих слоев композитов, полученных с использованием метода ориентационно-фазового контраста, показал, что вне околошовной зоны стали 09Г2С сохраняется исходная равноосная феррито-перлитная структура со сред-

Gladkovsky S.V. et al. / Formation of the mechanical properties and fracture resistance characteristics of sandwich composites based on the 09G2S steel and the EP678 high-strength steel of various dispersion 
ним размером зерна 12 мкм (рис. 4 a). На границе раздела слоев в стали 09Г2С имеется зона с равноосной рекристаллизованной структурой шириной до 5 мкм с размером кристаллитов 0,5-1 мкм (рис. 2 б и 5 a).

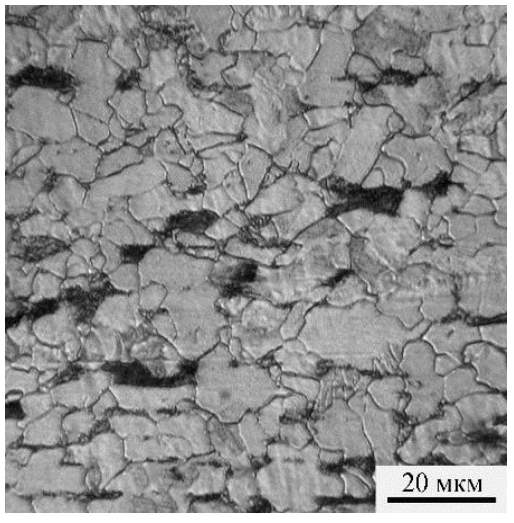

$a$

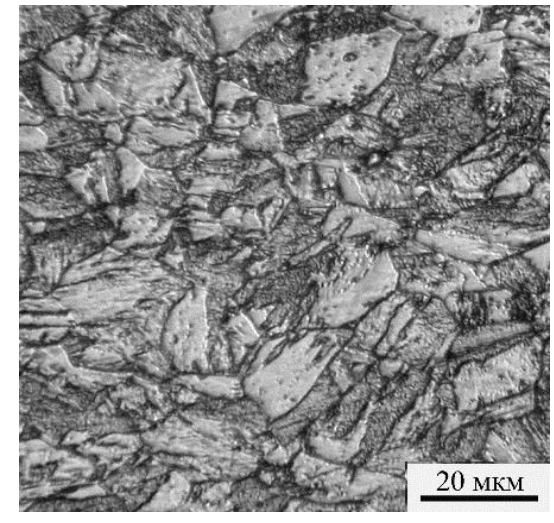

$\sigma$

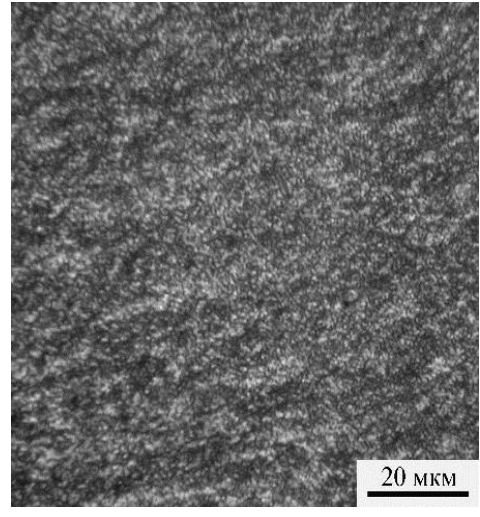

Рис. 4. Микроструктура составляющих 5-слойных композитов вне зоны сварного соединения: $a-09 Г 2 \mathrm{C} ; \sigma-Э П 678$ с МЗ структурой; $в-Э П 678$ с УМЗ структурой

Микроструктурный анализ слоев мартенситно-стареющей стали с МЗ структурой показал, что вне околошовной зоны структура стали представлена пакетным мартенситом и остаточным аустенитом (рис. 4 б). Средний размер аустенитного зерна в этой части слоя мартенситно-стареющей стали составляет 20 мкм. На границе сварных соединений выявлено наличие фрагментированной структуры протяженностью до 10 мкм (рис. 5 б). Средний размер зерна в приграничном диспергированном слое ЭП678 составляет около 200 нм.

В слоях сварного композита из стали ЭП678 после проведенной в ИПСМ РАН предварительной термопластической обработки практически на всех участках отмечается однородная УЗМ структура с размером зерна аустенита в пределах 50-200 нм (рис. 4 в и рис. 5 в). При этом идентифицировать структурные составляющие в стали ЭП678 после термопластической обработки в виду их высокой дисперсности с помощью используемых в данной работе методов микроструктурных исследований не представилось возможным.

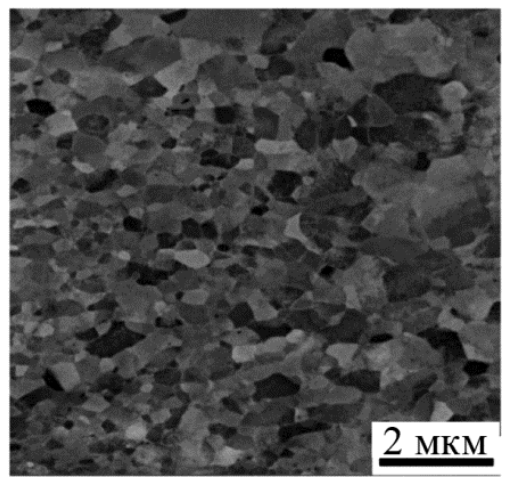

$a$

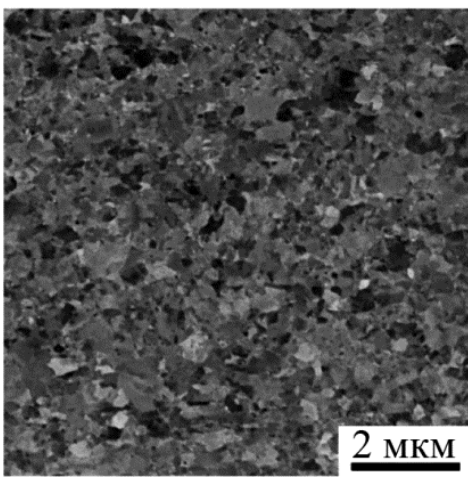

$\sigma$

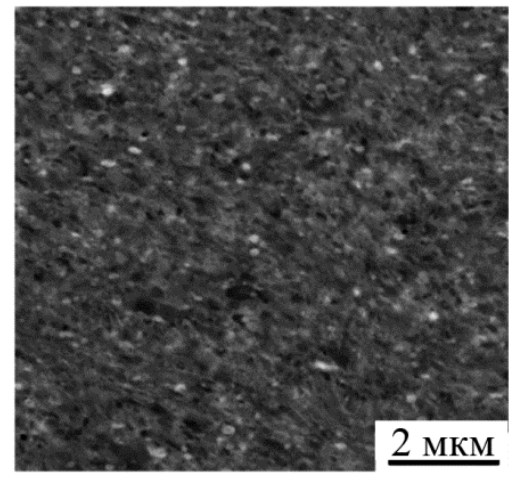

$B$

Рис. 5. Микроструктура составляющих 5-слойных композитов на расстоянии 5 мкм от границы сварного соединения: $a-09 Г 2 \mathrm{C} ; \sigma-$ ЭП678 с М3 структурой; в- ЭП678 с УМЗ структурой 
Полученные взрывным воздействием слоистые композиты подвергали дополнительной термообработке при $500{ }^{\circ} \mathrm{C}$ в течение 3 ч. Целью термической обработки готовых слоистых композитов является достижение максимального уровня прочностных свойств с сохранением высокой ударной вязкости композита, реализация которой возможна за счет упрочнения стали ЭП678 при сохранении пластичности стали 09Г2С. Выдержка при температуре $500{ }^{\circ} \mathrm{C}$ в закаленной МСС вызывает выделение дисперсных частиц интерметаллидов, что приводит к максимальному упрочнению сталей этого класса, а у низкоуглеродистых низколегированных сталей вызывает разупрочнение за счет перераспределения углерода и коагуляции карбидов.

Влияние последующей после сварки взрывом термической обработки на распределение легирующих элементов на границе слоев сварных композитов было оценено по результатам микрорентгеноспектрального анализа. Резкое изменение содержания основных легирующих элементов составляющих композитов сталей $(\mathrm{Cr}, \mathrm{Ni}, \mathrm{Mn}, \mathrm{Si})$ на границе соединения слоев сталей 09Г2С и ЭП678 происходит в достаточно узкой области, составляющей примерно 5-7 мкм (рис. 6). Это указывает на то, что проведенная после сварки взрывом термическая обработка не вызывает существенную активизацию диффузионных процессов на межслойных границах.

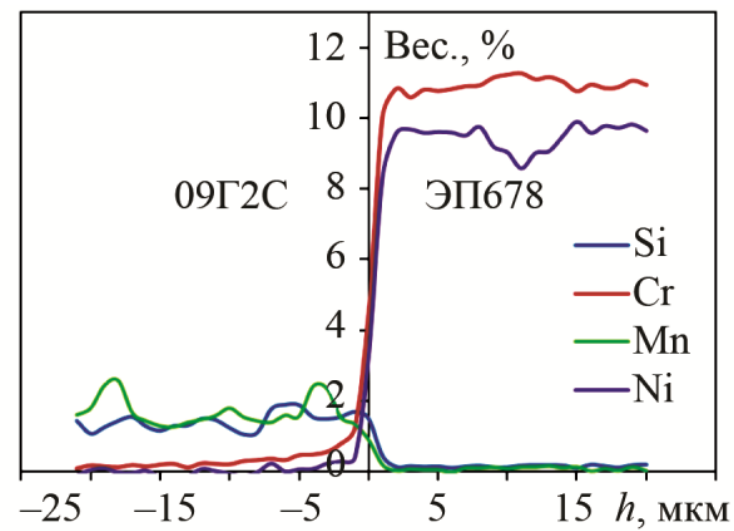

$a$

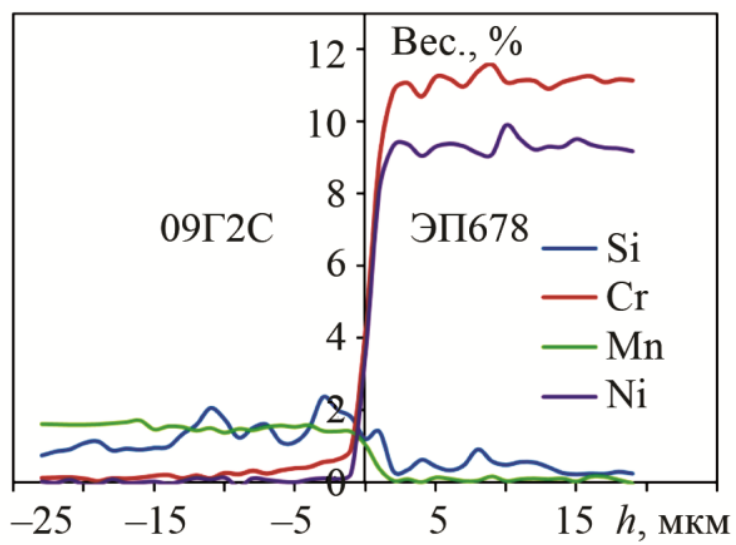

6

Рис. 6. Распределение элементов на границе раздела слоев 09Г2С и ЭП678 в 5-слойном сварном (a) и термообработанном (б) композите 2 (М3 МСС)

Режим проведенной термообработки для нормализованной стали 09Г2С является высоким отпуском, в ходе которого микроструктура стали меняется незначительно, а размер ферритных зерен сохраняется в пределах 12 мкм. В МСС данного типа при температуре старения выше $400{ }^{\circ} \mathrm{C}$ происходит образование метастабильной фазы $\beta$-Ni3Ti $\left(400-480{ }^{\circ} \mathrm{C}\right)$, а затем стабильной фазы $\eta-\mathrm{Ni} 3 \mathrm{Ti}\left(480-560^{\circ} \mathrm{C}\right)[15,16]$. Основными упрочняющими фазами в сталях типа 03X11H10М2Т являются интерметаллидная фаза Ni3 Ti с ГПУ решеткой и фаза Лавеса- $\lambda-\mathrm{Fe} 2(\mathrm{Ti}, \mathrm{Mo})$. Остаточный аустенит, присутствующий в исходной закаленной стали, в процессе охлаждения при старении за счет образования новых фаз обедняется легирующими элементами и превращается в мартенсит охлаждения. Таким образом, микроструктура ЭП678 по завершению термообработки состоит из пакетного мартенсита и дисперсных упрочняющих интерметаллидных частиц.

Сравнение микротвердости сталей 09Г2С и ЭП678 в исходном состоянии и после сварки взрывом в составе 5-слойного сварного композита позволило выявить некоторый прирост значений микротвердости в сварном композите обеих сталей на 8 \% (табл. 3). Как известно [17], упрочнение слоев композитов в процессе сварки взрывом происходит за счет высокоинтенсивной деформации составляющих композита взрывной волной. Сталь ЭП678, 
прошедшая термопластическую обработку на УМЗ структуру, имеет повышенные значения микротвердости в исходном состоянии и, соответственно, после сварки взрывом в отличие от этой же стали с МЗ структурой.

Таблица 3 - Микротвердость слоев в 5-СМКМ до и после сварки взрывом, а также дополнительной термообработки

\begin{tabular}{|l|c|c|c|}
\hline \multirow{2}{*}{ Состояние } & \multicolumn{3}{|c|}{ Микротвердость НV 0,05 } \\
\cline { 2 - 4 } & 09Г2С & $\begin{array}{c}\text { ЭП678 } \\
\text { (М3 структура) }\end{array}$ & $\begin{array}{c}\text { ЭП678 } \\
\text { (УМ3 структура) }\end{array}$ \\
\hline Исходное & 225 & 325 & 448 \\
\hline Сварка взрывом & 243 & 360 & 501 \\
\hline $\begin{array}{l}\text { Сварка взрывом + термическая обработка } \\
500{ }^{\circ} \mathrm{C}, 3 \text { ч, воздух }\end{array}$ & 234 & 570 & 515 \\
\hline
\end{tabular}

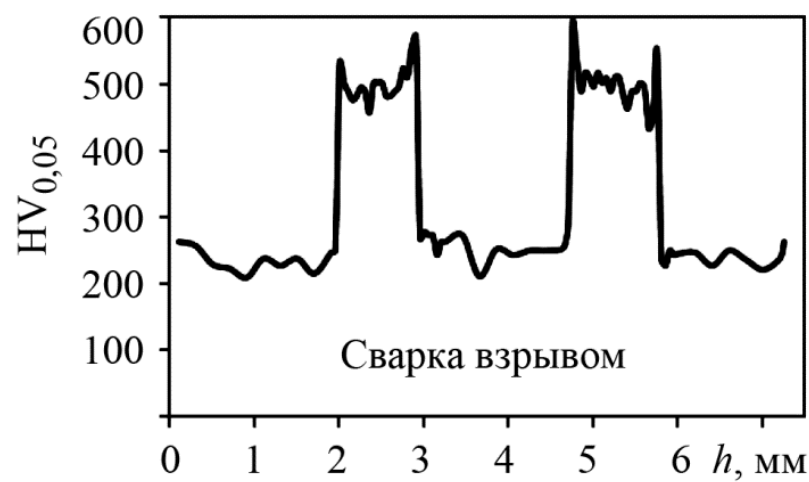

$a$

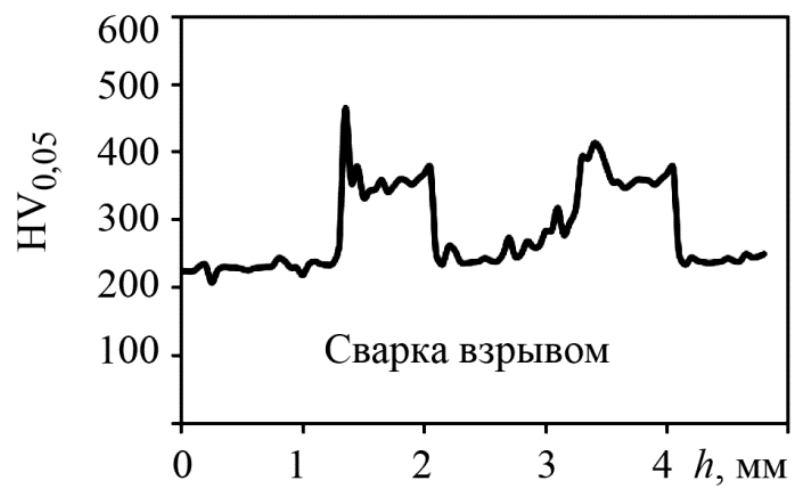

B

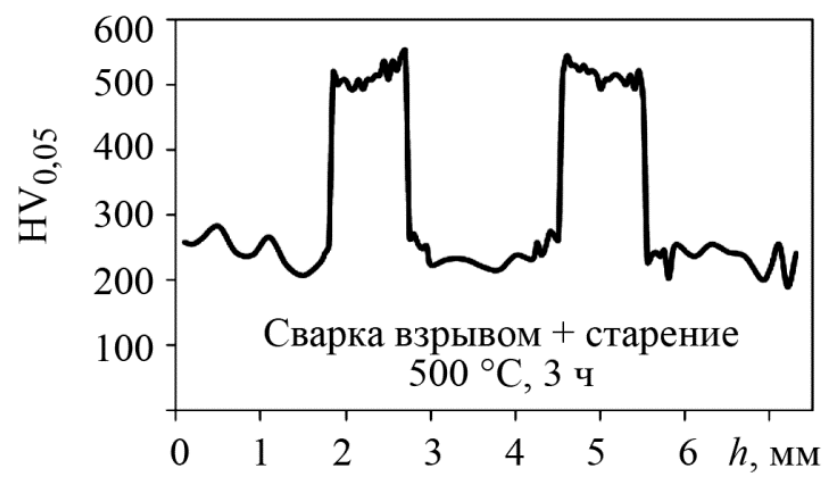

$\sigma$

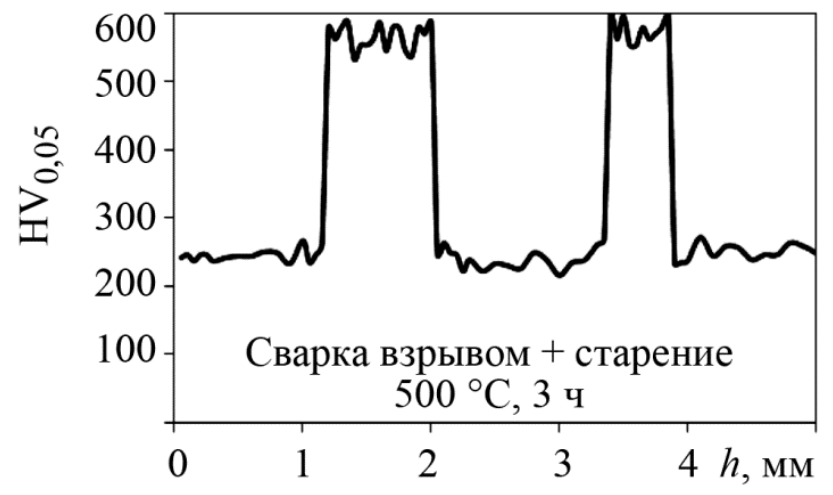

2

Рис. 7. Распределение микротвердости по ширине композитов $1(a, 6)$ и $2(b, 2)$ после сварки взрывом и после дополнительной термообработки

Однако дополнительное старение не приводит к ожидаемому сильному упрочнению стали ЭП678 с УМЗ структурой, прирост микротвердости составил всего 3 \%. Незначительный эффект упрочнения при термообработке композитов с прослойками из МСС с УМЗ структурой связан, вероятно, с прошедшим «перестариванием» стали ЭП678 в условиях нагрева до температуры $700{ }^{\circ} \mathrm{C}$ при термопластической обработке на УМЗ структуру. После дополнительной термообработки микротвердость прослоек стали ЭП678 с М3 структурой достигает самых высоких значений, а низкоуглеродистой низколегированной стали - незначительно снижается.

Gladkovsky S.V. et al. / Formation of the mechanical properties and fracture resistance characteristics of sandwich composites based on the 09G2S steel and the EP678 high-strength steel of various dispersion 
Из табл. 4 следует, что дополнительная термообработка (нагрев до $500{ }^{\circ} \mathrm{C}$ с выдержкой 3 ч.) оказывает неоднозначное влияние на механические свойства сталей 09Г2С и ЭП678, так как данный вид обработки для первой стали относится к высокому отпуску, а для второй - к упрочняющему старению. Так, дополнительный нагрев до $500{ }^{\circ} \mathrm{C}$ нормализованной стали 09Г2С приводит к некоторому снижению прочностных и повышению пластических свойств. Напротив, старение стали ЭП678 при указанной температуре вызывает существенный прирост значений $\sigma_{0,2}$ и $\sigma_{\text {B }}$, что сопровождается заметным уменьшением показателей пластичности $\delta$ и $\psi$. Повышение прочностных свойств предварительно перестаренной в процессе деформационной обработки при $700{ }^{\circ} \mathrm{C}$ стали ЭП678 с УМЗ структурой при последующем старении при более низкой температуре $\left(500{ }^{\circ} \mathrm{C}\right)$ происходит в значительно меньшей степени. Таким образом, термическая обработка композита данного состава позволяет регулировать соотношение прочностных свойств, оказывая одновременно упрочняющее и разупрочняющее воздействие на отдельные компоненты слоистого материала.

Таблица 4 - Механические свойства составляющих композита в исходном состоянии и после термообработки

\begin{tabular}{|c|l|c|c|c|c|}
\hline \multicolumn{2}{|c|}{ Материал и режим обработки } & $\sigma_{0,2}, \mathrm{MПа}$ & $\sigma_{\mathrm{B}}, \mathrm{MПа}$ & $\delta, \%$ & $\psi, \%$ \\
\hline 1 & 09Г2С нормализация с $920{ }^{\circ} \mathrm{C}$ & 385 & 500 & 33 & 71 \\
\hline 2 & 09Г2С нормализация $920{ }^{\circ} \mathrm{C}+$ отпуск $500{ }^{\circ} \mathrm{C}, 3$ ч & 363 & 486 & 55 & 74 \\
\hline 3 & ЭП678 (М3 структура) закалка $920{ }^{\circ} \mathrm{C}$ & 850 & 1030 & 11 & 77 \\
\hline 4 & ЭП678 (М3 структура) старение $500{ }^{\circ} \mathrm{C}, 3$ ч & 1370 & 1522 & 4 & 36 \\
\hline 5 & ЭП678 (УМ3 структура) & 1003 & 1310 & 9 & 28 \\
\hline 6 & ЭП678 (УМ3 структура) старение $500{ }^{\circ} \mathrm{C}, 3$ ч & 1156 & 1340 & 7 & 27 \\
\hline
\end{tabular}

Исходя из результатов проведенных механических испытаний на растяжение (табл. 5) видно, что наиболее высокий уровень прочностных свойств достигается в сварных композитах, имеющих в составе прослойки УМЗ МСС, без проведения последующей термической обработки композита $\left(\sigma_{\mathrm{B}}=882 \mathrm{MПа,} \sigma_{0,2}=772 \mathrm{MПа}\right)$. Дополнительная термическая обработка не оказывает существенного упрочнения в слоях УМЗ стали ЭП678, вследствие предварительного перестаривания данной стали в процессе термопластической обработки, предшествующей сборке пакета и получению композита методом сварки взрывом, а в основном способствует пластификации композита за счет отпуска слоев 09Г2С, благодаря чему значения относительного удлинения $(\delta)$ и относительного сужения $(\psi)$ возрастают с 7 до $15 \%$ и с 27 до $36 \%$ соответственно. Упрочняющий эффект за счет старения МСС слоев наиболее заметен на слоистых композитах с МЗ сталью ЭП678, прочностные свойства которого возрастают с $\sigma_{\mathrm{B}}=745 \mathrm{MПа;}$ $\sigma_{0,2}=705$ МПа до $\sigma_{\mathrm{B}}=855 \mathrm{MПа;} \sigma_{0,2}=770 \mathrm{MПа,} \mathrm{при} \mathrm{этом} \mathrm{пластические} \mathrm{свойства} \mathrm{не-}$ сколько снижаются. 
Таблица 5 - Механические свойства композита и его составляющих в исходном состоянии и после термообработки

\begin{tabular}{|c|c|c|c|c|c|}
\hline № П.П & Материал & $\sigma_{0,2}, \mathrm{M \Pi а}$ & $\sigma_{\mathrm{B}}, \mathrm{MПа}$ & $\delta, \%$ & $\psi, \%$ \\
\hline 1 & $\begin{array}{l}\text { 5-СМКМ (ЭП678 с УМЗ структурой), } \\
\text { сварка взрывом }\end{array}$ & 772 & $882 / 703^{*}$ & 7 & 27 \\
\hline 2 & $\begin{array}{l}\text { 5-СМКМ (ЭП678 с УМЗ структурой), } \\
\text { сварка взрывом + ТО } 500{ }^{\circ} \text { С, } 3 \text { ч }\end{array}$ & 695 & $866 / 700^{*}$ & 15 & 36 \\
\hline 3 & $\begin{array}{l}\text { 5-СМКМ (ЭП678 с МЗ структурой), } \\
\text { сварка взрывом }\end{array}$ & 705 & $745 / 632^{*}$ & 15 & 46 \\
\hline 4 & $\begin{array}{l}\text { 5-СМКМ (ЭП678 с МЗ структурой), } \\
\text { сварка взрывом + ТО } 500{ }^{\circ} \mathrm{C}, 3 \text { ч }\end{array}$ & 770 & $855 / 745^{*}$ & 10 & 31 \\
\hline
\end{tabular}

*Расчетные значения временного сопротивления, вычисленные по правилу смесей.

Экспериментальные значения временного сопротивления изученных 5-слойных композитов сопоставлялись с расчетными значениями $\sigma_{\text {в }}$, которые рассчитывались по правилу смесей (аддитивности) [18]:

$$
\sigma_{\mathrm{B}}^{P}=\sigma_{\mathrm{B} 1} \cdot f_{1}+\sigma_{\mathrm{B} 2} \cdot f_{2}
$$

где $\sigma_{\mathrm{B} 1}$ и $\sigma_{\mathrm{B} 2}-$ временное сопротивление 1 и 2-й составляющих композита; $f_{1}$ и $f_{2}$ - объемные доли 1 и 2-й составляющих композита.

Для расчета значений временного сопротивления СМКМ после сварки взрывом и дополнительной термообработки использовались экспериментальные данные по прочности составляющих композита в исходном состоянии и после термической обработки, соответственно с учетом того, что объемная доля МСС в композите соответствовала 25 \% (табл. 3). Экспериментальные значения временного сопротивления для всех типов, изученных СМКМ значительно превосходят расчетные значения. По-видимому, более высокие экспериментальные значения прочности по сравнению с расчетными связаны с упрочняющим влиянием сварки взрыва на металл составляющих композита [12]. Наибольшая разница между экспериментальными и расчетными значениями временного сопротивления наблюдается у композита 2 (УМЗ МСС).

Результаты ударных испытаний составляющих композитов показали, что с понижением температуры испытания от +20 до $-60{ }^{\circ} \mathrm{C}$ ударная вязкость стали $09 Г 2 \mathrm{C}$ снижается от значений

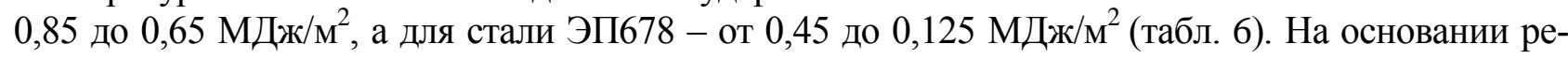
зультатов ударных испытаний композитов с ориентацией надреза по тормозящему типу «сrackarrester» было установлено, что сварной композит 1 (УМЗ МСС) имеет более высокие значения характеристик ударной вязкости по сравнению со сварным композитом 2 (МЗ МСС) (табл. 7).

Таблица 6 - Характеристики ударной вязкости составляющих слоистого композита «09Г2С-ЭП678»*

\begin{tabular}{|c|c|c|c|c|c|c|}
\hline \multirow{2}{*}{ Сталь } & \multirow{2}{*}{$T_{\text {исп. }}{ }^{\circ} \mathrm{C}$} & \multicolumn{5}{|c|}{ Характеристики ударной вязкости } \\
\cline { 3 - 7 } & 20 & $K C V, \mathrm{MДж/ \textrm {M } ^ { 2 }}$ & $A$, Дж & $A_{3}$, Дж & $A_{\mathrm{p}}$, Дж & $J i_{\mathrm{d}}, \mathrm{MДж/ \textrm {M } ^ { 2 }}$ \\
\hline \multirow{2}{*}{ 09Г2С } & 20 & 0,85 & 31,60 & 6,86 & 24,74 & 0,37 \\
\cline { 2 - 7 } & -60 & 0,65 & 26,26 & 6,60 & 19,66 & 0,33 \\
\hline \multirow{2}{*}{ ЭП678 } & 20 & 0,45 & 46,50 & 26,90 & 19,60 & 0,49 \\
\cline { 2 - 6 } & -60 & 0,125 & 12,90 & 11,70 & 1,20 & 0,30 \\
\hline
\end{tabular}

"Ударные испытания стали 09Г2С проводились на образцах размером $5 \times 10 \times 55$ мм, а стали ЭП678 - на образцах размером 10×10×55 мм (типа 11 и 13 по ГОСТ 9454 соответственно) 
Таблица 7 - Результаты ударных испытаний 5-слойных сварных композитов

\begin{tabular}{|c|c|c|c|c|c|c|c|}
\hline \multirow{2}{*}{$\begin{array}{l}\text { № } \\
\text { П.П. }\end{array}$} & \multirow{2}{*}{ Композиты } & \multirow{2}{*}{$T_{\text {исп. }},{ }^{\circ} \mathrm{C}$} & \multicolumn{5}{|c|}{ Характеристики ударной вязкости } \\
\hline & & & $\begin{array}{c}K C V, \\
\mathrm{MД} / \mathrm{M}^{2}\end{array}$ & A, Дж & $A_{3}$, Дж & $A_{\mathrm{p}}$, Дж & $\begin{array}{c}J i_{\mathrm{d}}, \\
\mathrm{MД} / \mathrm{M}^{2}\end{array}$ \\
\hline \multirow{2}{*}{1} & \multirow{2}{*}{$\begin{array}{c}\text { Композит } 1 \\
\text { (УМЗ МСС), } \\
\text { сварка взрывом }\end{array}$} & 20 & $>0,92$ & $>40,56$ & 12,01 & - & 0,55 \\
\hline & & -60 & $>1,09$ & $>44,96$ & 12,70 & - & 0,58 \\
\hline \multirow{2}{*}{2} & \multirow{2}{*}{$\begin{array}{c}\text { Композит 1 } \\
\text { (УМ3 МСС), } \\
\text { сварка взрывом + } \\
\text { старение } 500{ }^{\circ} \mathrm{C}, 3 \text { ч }\end{array}$} & 20 & $>1,23$ & $>51,6$ & 12,05 & - & 0,58 \\
\hline & & -60 & $>1,29$ & $>53,15$ & 20,54 & - & 1,0 \\
\hline \multirow{2}{*}{3} & \multirow{2}{*}{$\begin{array}{c}\text { Композит } 2 \text { (М3 МСС), } \\
\text { сварка взрывом + } \\
\text { старение } 500{ }^{\circ} \mathrm{C}, 3 ч\end{array}$} & 20 & $>0,67$ & $>25,55$ & 8,90 & - & 0,46 \\
\hline & & -60 & 0,42 & 16,49 & 4,25 & 12,24 & 0,22 \\
\hline
\end{tabular}

Примечание. Большинство образцов, кроме образца № 3, испытанного при температуре -60 ${ }^{\circ} \mathrm{C}$, при ударных испытаниях полностью не разрушилось, поэтому ударная вязкость и полная работа разрушения обозначается как $K C V>\ldots$ и $A>\ldots$, а определение работы распространения трещины только при частичном разрушении образца является неправомерным.

Следует особо отметить выявленный аномальный эффект повышения характеристик ударной вязкости $\left(K C V, A_{3}\right.$ и $\left.J i_{\mathrm{d}}\right)$ композита 1 (УМ3 МCC) непосредственно после сварки взрывом и, особенно, после дополнительного старения/отпуска при $500{ }^{\circ} \mathrm{C}, 3$ ч с понижением температуры испытаний от комнатной до $-60^{\circ} \mathrm{C}$. Для композита 2 (M3 MCC) понижение температуры испытаний от +20 до $-60{ }^{\circ} \mathrm{C}$ приводит к полному разрушению образца и снижению изученных характеристик ударной вязкости и динамической трещиностойкости при сохранении достаточно высокого сопротивления материла хрупкому разрушению при динамических нагрузках. При этом работа на распространение трещины в композите 2 более чем в 2 раза выше по сравнению с работой зарождения трещины, что указывает на повышенную конструкционную прочность слоистого материала.

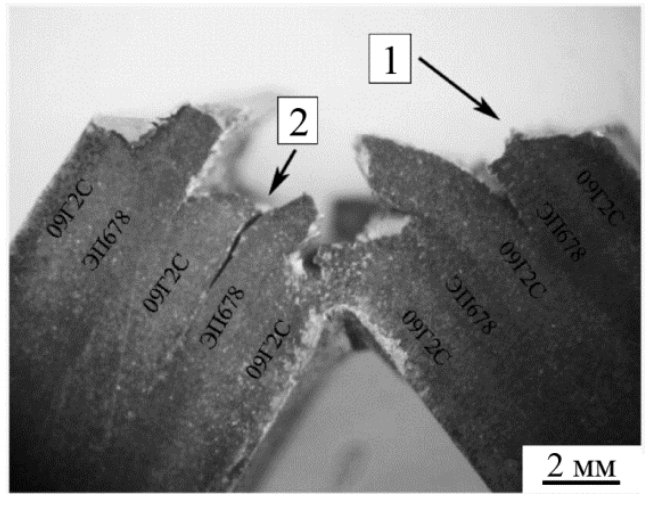

$a$

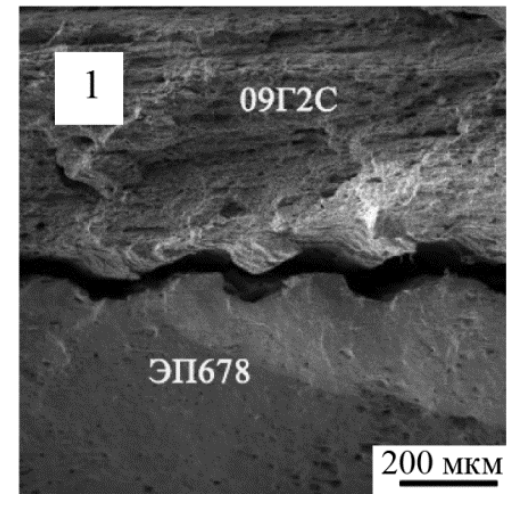

$\sigma$

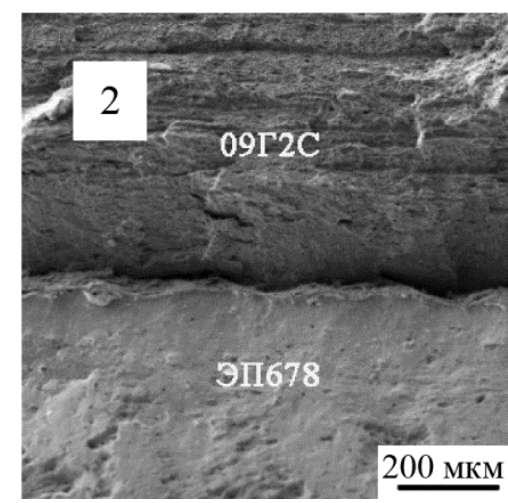

B

Рис. 8. Боковой вид испытанного при $20{ }^{\circ} \mathrm{C}$ ударного образца $(a)$ и микростроение границ раздела слоев 09Г2С и ЭП678 $(\sigma, \varepsilon)$ в изломе 5-слойного сварного композита 1 (УМЗ МСС) 


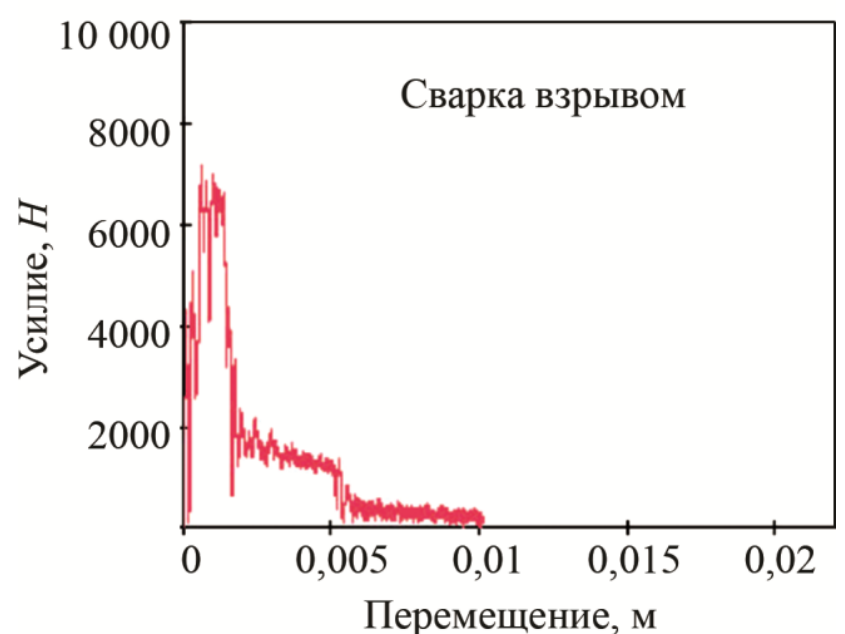

$a$

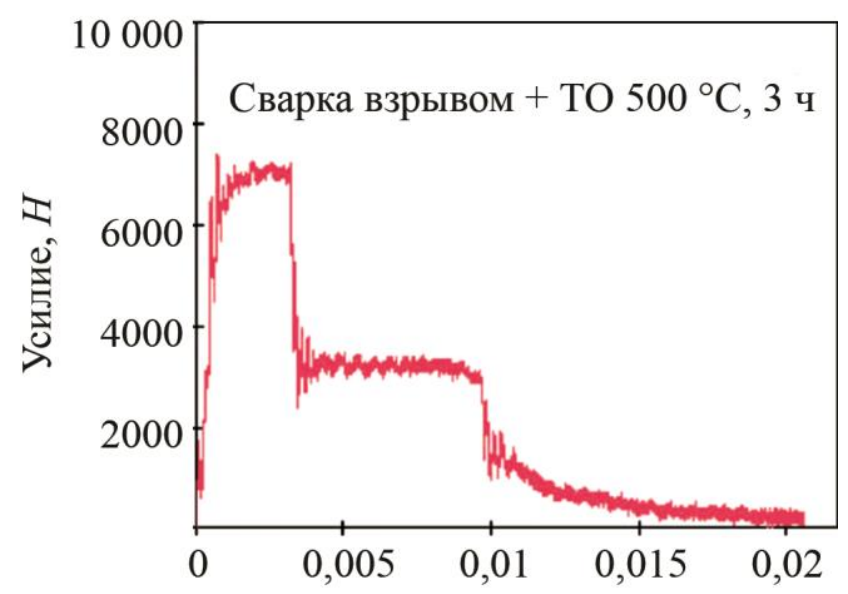

Перемещение, м

B

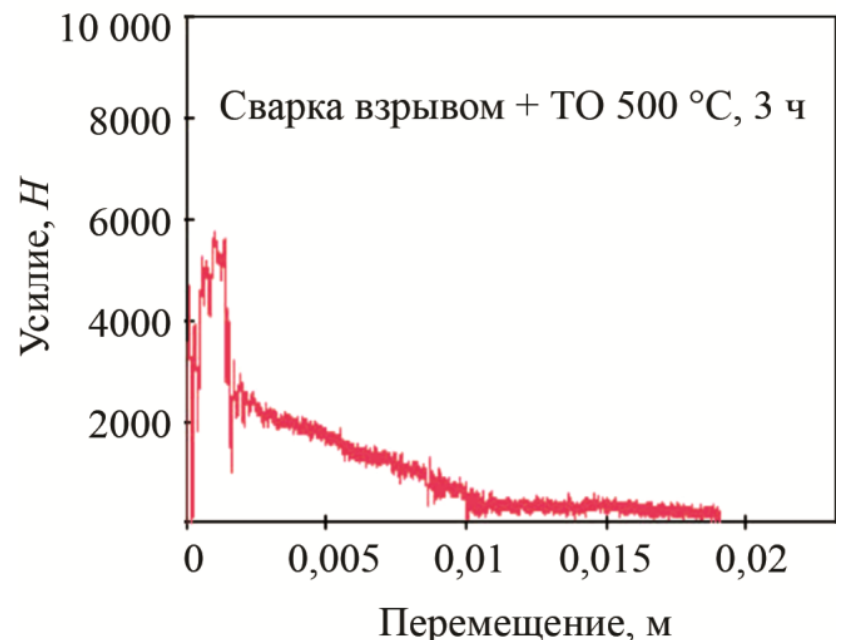

$\partial$

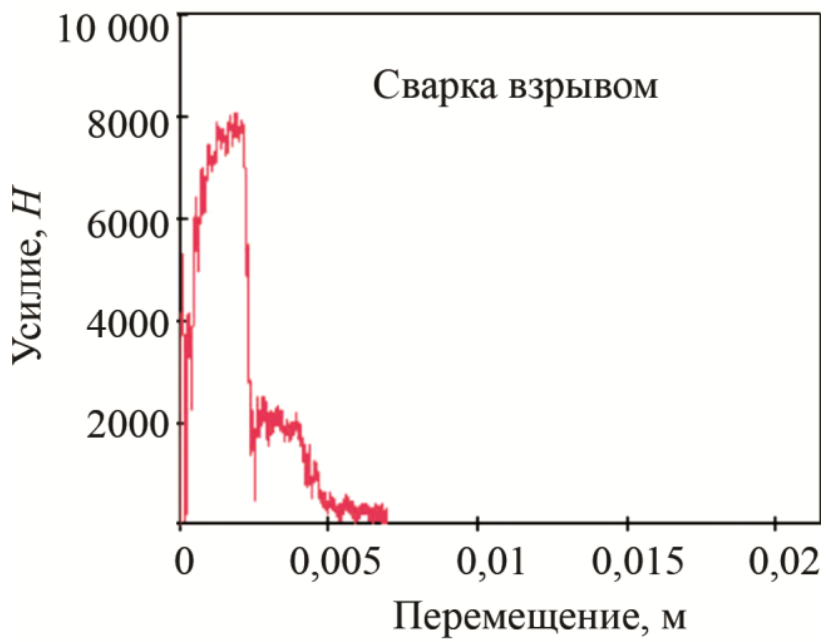

$\sigma$

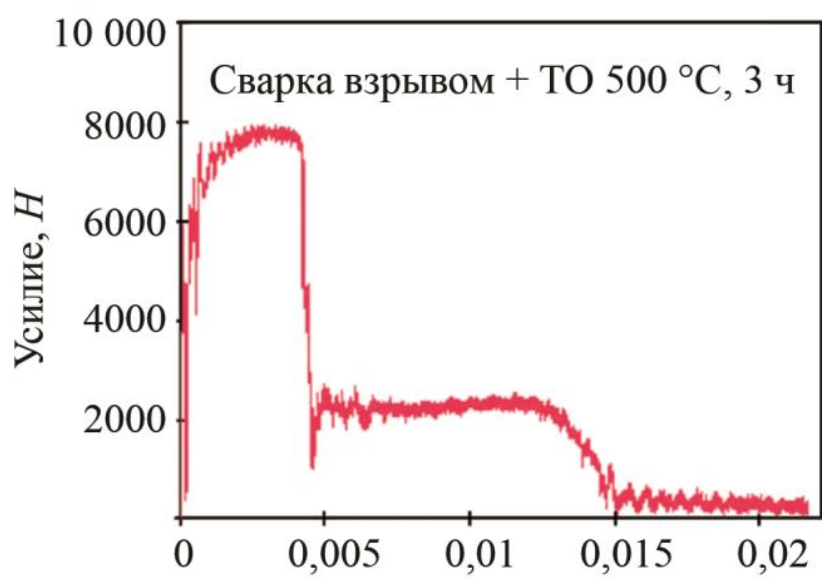

Перемещение, м

2

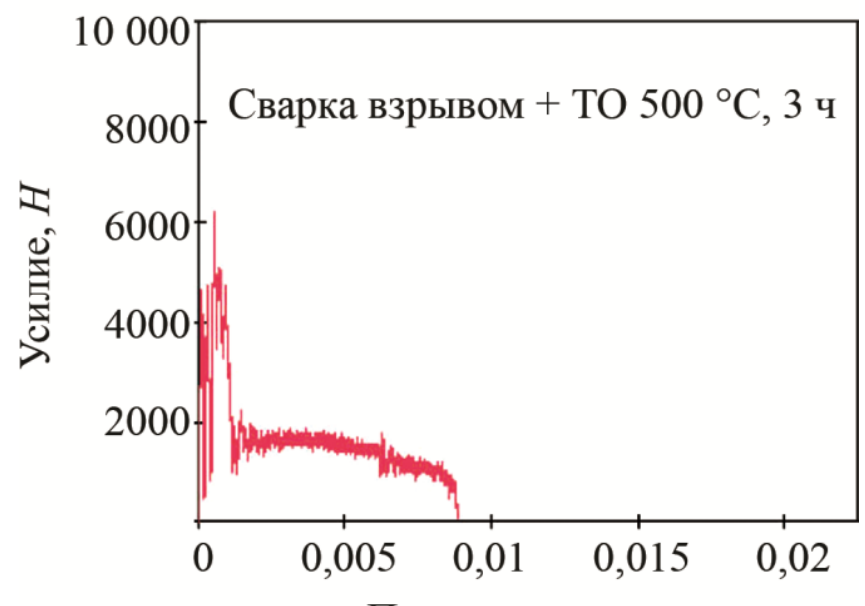

Перемещение, м

Рис. 9. Диаграммы ударного нагружения при температурах $20{ }^{\circ} \mathrm{C}(a, b, \partial)$ и $-60{ }^{\circ} \mathrm{C}(\sigma, 2, e)$ композитов с УМЗ $(a, \sigma, \varepsilon, 2)$ и МЗ $(\partial, e)$ слоями стали ЭП678 после сварки взрывом и дополнительной термообработки

Gladkovsky S.V. et al. / Formation of the mechanical properties and fracture resistance characteristics 
При ударных испытаниях формирующаяся в вершине V-образного надреза трещина в большинстве случаев проходит только через несколько слоев композита. При этом на межслойных границах происходит незначительное отклонение траектории трещины вдоль границы раздела с образованием расщеплений различной длины, что способствует торможению трещины и повышению характеристик ударной вязкости. Следует отметить, что выявленные металлографическим методом и описанные выше типы волнообразных и плоских сварных границ (рис. 1) отчетливо проявляются и на фрактограммах ударных образцов композиционных материалов (рис. 8 б, в).

Наблюдаемая стадийность процесса продвижения трещины хорошо прослеживается и на диаграммах нагружения ударных образцов, на которых можно выделить 3 стадии процесса разрушения СМКМ. Начальное повышение динамической нагрузки и ее резкое падение связано с формированием острой трещины и ее ростом до образования перпендикулярно ориентированной ей трещины расслоения. Второй участок с постоянной или несколько снижающейся нагрузкой соответствует дальнейшему прохождению трещины в первоначальном направлении, а на третьем участке трещина затормаживается и происходит изгиб неразрушенного образца до полного снятия нагрузки. На диаграмме ударного нагружения полностью разрушенного образца композита с М3 прослойкой ЭП678, испытанного при температуре $-60{ }^{\circ} \mathrm{C}$, соответствующий изгибу последних слоев композита третий участок полностью отсутствует (рис. 9 e).

Анализ микромеханизмов послойного разрушения ударных образцов 5-слойных термообработанных композитов 1 и 2 показал, что при комнатной температуре испытания все стальные слои в обоих композитах разрушаются по вязкому механизму с образованием типичного ямочного излома. При низкотемпературных испытаниях композитов, прошедших термообработку, разрушение протекает по хрупкому механизму только в слоях стали 09Г2С с формированием фасеток квазискола на поверхности разрушения (рис. $10 a$ ) а слои стали ЭП678 с МЗ и УМЗ структурой по-прежнему разрушаются по вязкому механизму с образованием ямочного строения излома (рис. $10 \sigma$, в). Отличительной особенностью разрушения слоев УМЗ стали ЭП678 в состаренном состоянии является формирование топографии излома из особо мелких ямок, распознаваемых только при большом увеличении.

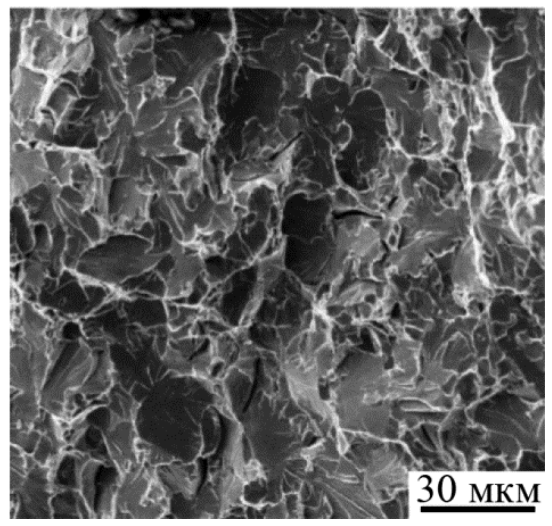

$a$

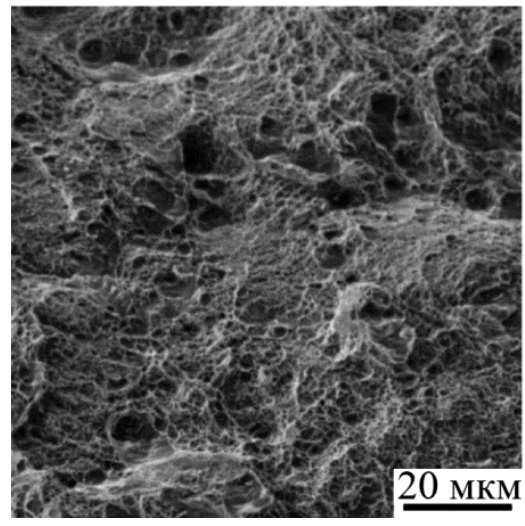

6

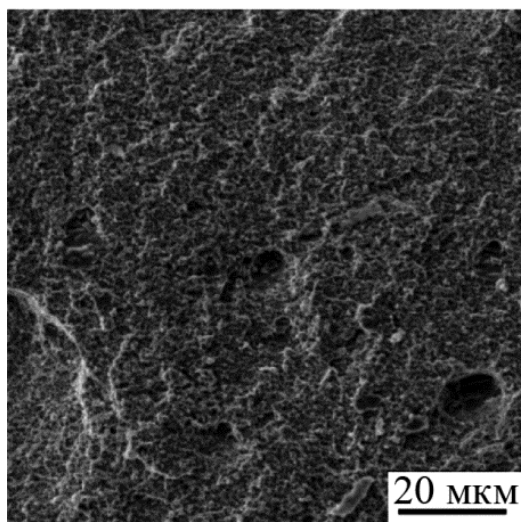

B

Рис. 10. Микрофрактограммы слоев 09Г2С (a) и ЭП678 с МЗ (б) и УМЗ (в) структурами в составе 5-слойных термообработанных композитов после ударных испытаний при $-60{ }^{\circ} \mathrm{C}$

По результатам циклических испытаний СМКМ после сварки взрывом и материала основы стали 09Г2С получена зависимость скорости роста трещины от размаха коэффициента интенсивности напряжений цикла $\Delta K$, представленная в виде кинетической диаграммы усталостного разрушения (КДУР) (рис. 11). Следует отметить, что в области достигнутых 
значений $\Delta K<35 \mathrm{MПа} \cdot \mathrm{M}^{1 / 2}$ скорость роста усталостной трещины в слоях стали 09Г2С в составе композита существенно ниже, чем в монолитном образце из стали аналогичного состава. По-видимому, это связано с конструктивными особенностями слоистого материала, механическое поведение которого при циклическом нагружении определяется не только отдельными разнопрочными слоями, но и интегральными свойствами всего композита.

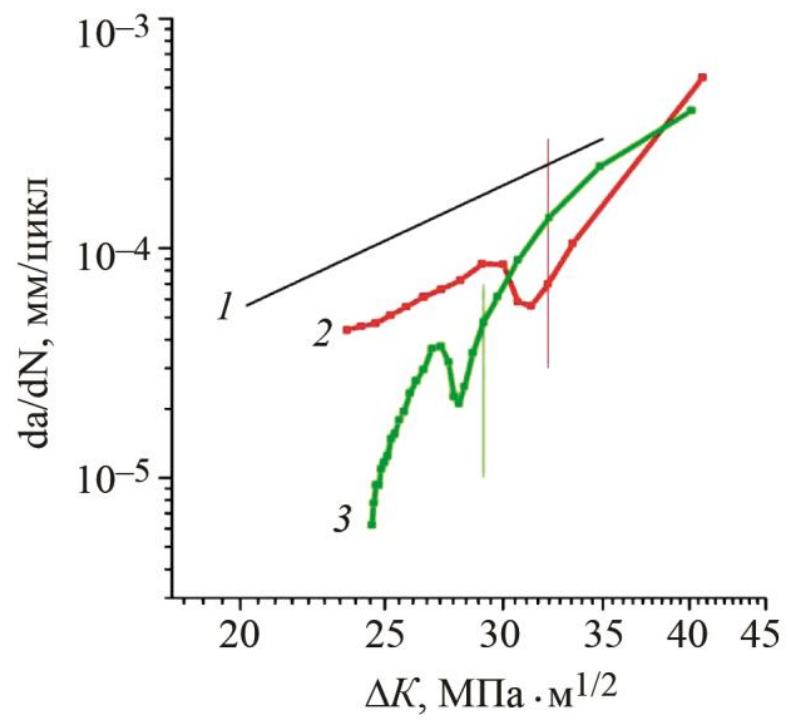

Рис. 11. Кинетические диаграммы роста усталостной трещины в монолитном образце 09Г2С и в слоях стали 09Г2С в составе 5-слойного сварного композита с прослойками стали ЭП678 различной дисперсности: 1 - монолитный образец из стали 09Г $2 \mathrm{C} ; 2$ - композит со слоями стали ЭП678 с мелкозернистой структурой (МЗ); 3 - композит со слоями стали ЭП678

с ультрамелкозернистой структурой (УМЗ). Вертикальные линии соответствуют границе перехода из слоя 09Г2С в слой ЭП678

При этом в области значений размаха $\Delta K=25-30 \mathrm{MПа} \cdot \mathrm{M}^{1 / 2}$ более высокой циклической трещиностойкостью обладает композит 1 (УМЗ МСС) по сравнению с композитом 2 (М3 МСС). При более высоких значениях размаха $\Delta K$ свыше $30 \mathrm{MПа} \cdot \mathrm{M}^{1 / 2}$ преимущество в циклической трещиностойкости композита 1 (УМЗ МСС) и дисперсность прослоек стали ЭП678 не оказывает заметного влияния на скорость роста усталостной трещины в композите. По результатам фрактографических исследований (рис. 12) установлено, что процесс роста усталостной трещины в изученном слоистом композите на макроуровне развивается по типу монолитного материала. При этом прохождение фронта усталостной трещины границы раздела слоев сталей 09Г2С и ЭП678 не сопровождается изменением рельефа поверхности разрушения и появлением характерных для статического и динамического нагружения расслоений (рис. $12 a$, г).

Изучение микростроения поверхности усталостной трещины слоистого материала на участке ее роста, соответствующему достигнутым значениям размаха $\Delta K=25-32 \mathrm{MПа} \cdot \mathrm{M}^{1 / 2}$ показало, что в композитах 1 и 2 усталостный излом имеет сложный развитый рельеф, характеризующийся наличием смешанных статических и циклических мод нагружения [9]. При этом микростроение поверхности усталостной трещины в слоях стали 09Г2С композитов 1 и 2 практически не различается, и в композите 1 отсутствуют типичные для полученных при циклическом нагружении изломов усталостные бороздки (рис. 12 б, $\partial$ ). Напротив, строение зоны усталостного роста трещины в слоях стали ЭП678 с УМЗ и МЗ структурами существенно различаются. В слоях стали ЭП678 с УМЗ структурой (композит 1) излом имеет более плоский вид, в нем присутствуют усталостные бороздки (рис. 12 в). В зоне усталости стали ЭП678 с М3 структурой (композит 2) усталостные бороздки частично вырождены, а его рельеф очень напоминает поверхность роста усталостной трещины в слоях стали 09Г2С (рис. $12 e$ ). 


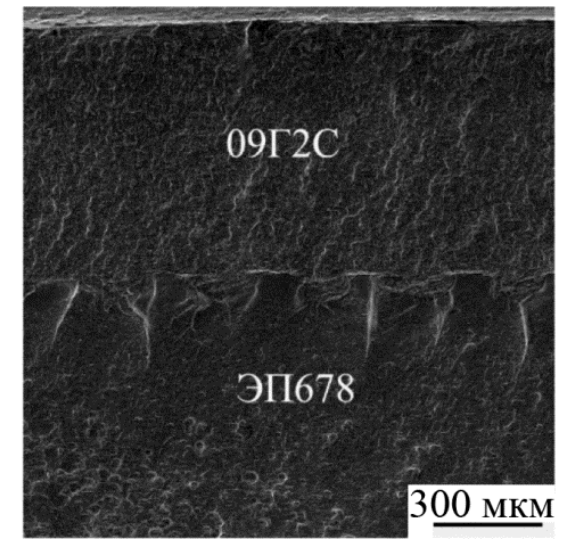

$a$

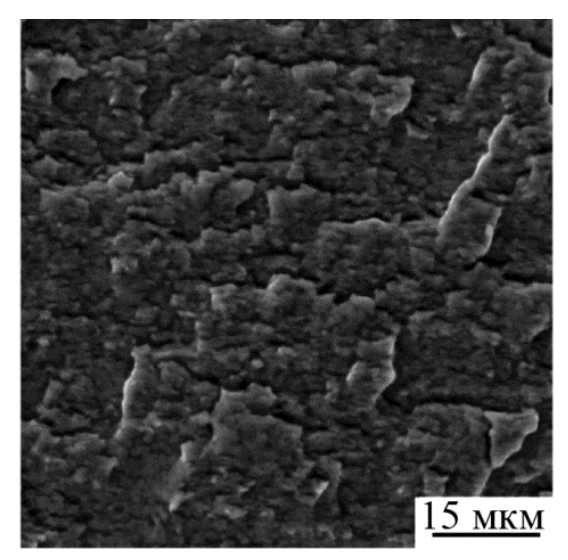

B

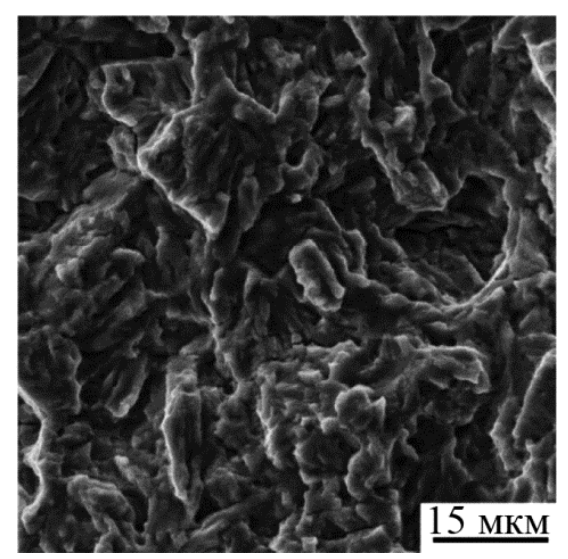

$\partial$

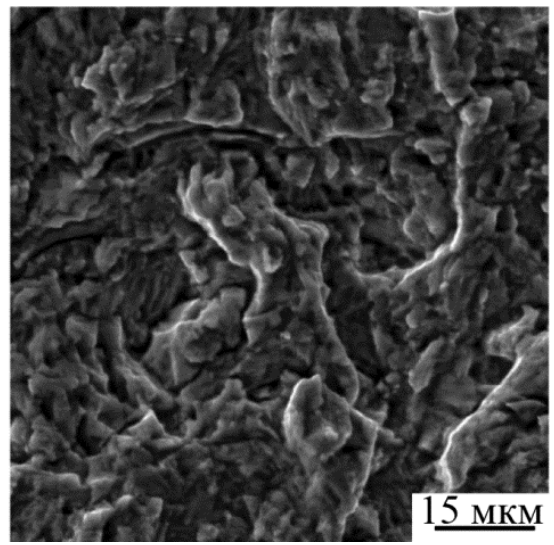

$\sigma$

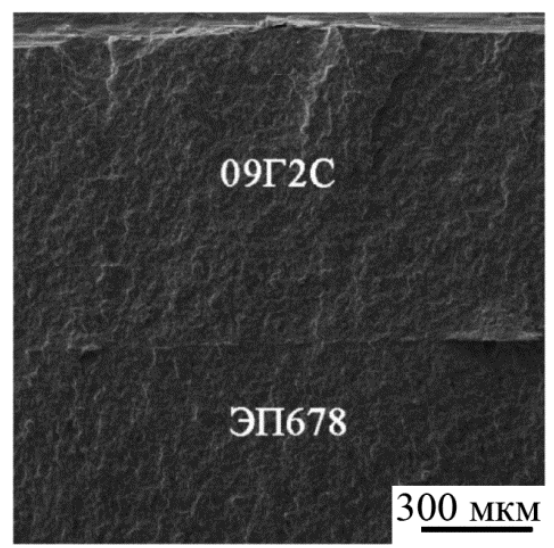

2

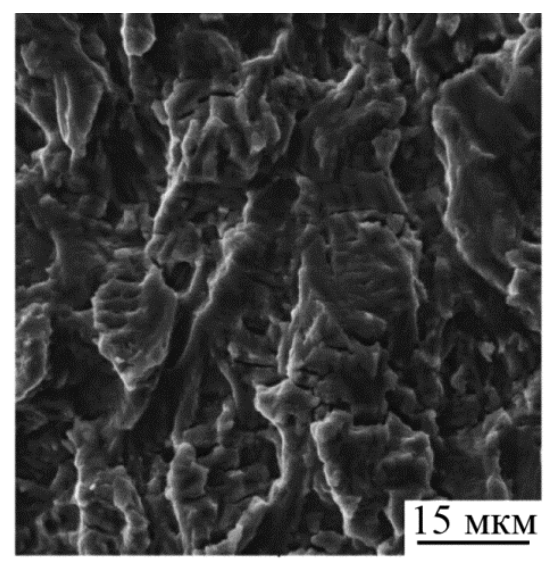

$e$

Рис. 12. Микростроение поверхности циклического роста трещины при прохождении границы соединения слоев сталей 09Г2С и ЭП678: $a, \sigma, ~ в-$ композит 1 (УМЗ ЭП678); г, д, $e$ - композит 2 (М3 ЭП678); б, г - слои 09Г2С; в, $e-$ слои ЭП678 с УМЗ и МЗ структурой 


\section{4. Заключение}

Сформированные при сварке взрывом 5-слойные неразъемные соединения на основе сталей 09Г2С и ЭП678 характеризуются прямолинейными и волнообразными границами раздела слоев. Строение межслойных границ последнего типа в продольном сечении образцов может быть описано тригонометрическими функциями. На границах соединения слоев отсутствуют часто наблюдаемые в сварных соединениях дефекты в виде пор и неметаллических включений, а также охрупчивающие карбидные и интерметаллидные частицы. Граница соединения слоев сталей 09Г2С и ЭП678 характеризуется достаточно узкой диффузионной зоной, составляющей примерно 5-7 мкм.

При сварке взрывом на границе соединения слоев 09Г2С и ЭП678 с обеих сторон формируются зоны протяженностью до 10 мкм с фрагментированной УМЗ структурой с размерами кристаллитов от 0,2 до 1 мкм, сменяющихся в направлении к центральной части слоев на крупнокристаллическую структуру со средними размерами зерен феррита 12 мкм в стали 09Г2С и аустенита 20 мкм в стали ЭП678.

Значения временного сопротивления сварных СМКМ на основе сталей 09Г2С и ЭП678 в 1,3-1,4 раза превышают уровень прочности данных материалов, рассчитанной по правилу смесей. Наиболее высокие значения $\sigma_{\mathrm{B}}=866-882$ МПа достигаются в слоистых композитах со слоями УМЗ стали ЭП678 с размером структурных элементов 50-200 нм.

Показана возможность регулирования комплекса механических свойств слоистого композита путем дополнительной термической обработки (нагрев до $500{ }^{\circ} \mathrm{C}$ с выдержкой 3 ч), одновременно приводящей к упрочнению слоев стали ЭП678 в результате старения и разупрочнению слоев стали 09Г2С при отпуске.

Изученные сварные слоистые композиты характеризуются высокими характеристиками ударной вязкости и динамической трещиностойкости при условии расположения концентратора напряжений по «тормозящему» типу (перпендикулярно плоскости сопряжения слоев). Повышение сопротивления данных материалов хрупкому разрушению при динамическом нагружении при комнатной и пониженных температурах, связано с частичным ответвлением траектории трещины вдоль границ раздела, вызывающим расслоение композита и соответственно торможение роста трещины. Обнаружен эффект аномального роста характеристик ударной вязкости СМКМ с УМЗ прослойками стали ЭП678 с понижением температуры ударных испытаний от комнатной до $-60{ }^{\circ} \mathrm{C}$.

Показано, что в области значений размаха коэффициента интенсивности напряжений $\Delta K<35 \mathrm{MПа} \cdot{ }^{1 / 2}$ скорость роста усталостной трещины в слоях стали 09Г2С в составе композита ниже, чем в монолитном образце из стали аналогичного состава. При этом области значений $\Delta K=25-31 \mathrm{MПа} \cdot{ }^{1 / 2}$ СМКМ с прослойками МСС ЭП678 с УМЗ структурой обладают более высокой циклической трещиностойкостью по сравнению с композитами, содержащими слои стали ЭП678 с М3 структурой при одинаковой объемной доле высокопрочной $\operatorname{MCC}(25 \%)$.

Выявлен эффект торможения усталостной трещины в СМКМ при ее прохождении межслойных границ из менее прочного слоя стали 09Г2С в более прочный слой стали ЭП678, проявляющийся в характерных провалах на кинетических диаграммах усталостного разрушения. Определены фрактографические особенности роста усталостных трещин в различных слоях композитов при различных значениях $\Delta K$ в вершине усталостной трещины.

На основе анализа макро- и микростроения изломов изученных СМКМ показано, что разрушение изученных слоистых материалов в условиях статического и динамического роста трещины происходит по композитному типу с образованием расслоений, а при циклическом нагружении - по типу монолитного материала с образованием плоского рельефа поверхности разрушения. 


\section{Благодарность}

Работа выполнена при частичной поддержке проекта УрО РАН № 15-15-1-52 (программа «Арктика») в части изучения характеристик ударной вязкости и динамической трещииностойкости при комнатной и пониженной температурах, в рамках гранта РФФИ № 16-38-00723мол_а в части исследования ииклической трещиностойкости слоистых композитов и в рамках выполнения Госзадания № 01201375904 в части изучения микроструктуры отдельных слоев композитов и строения межслойных границ.

Авторы выражают благодарность м.н.с. С. Н. Сергееву (ИПСМ РАН, г. Уфа) за помощь в проведении структурных исследований слоистых композитов.

Исследования выполнены на оборудовании ЦКП «Пластометрия» ИМАШ УрО РАН.

\section{Литература}

1. Chawla N., Chawla K. N. Metal matrix Composites. - 2nd ed. - New York : Springer Science+Business Media, 2013. - 370 pp. - DOI: https://doi.org/10.1007/978-0-387-74365-3_6

2. Производство металлических слоистых композиционных материалов / А. Г. Кобелев, В. И. Лысак, В. Н. Чернышев, А. А. Быков, В. П. Востриков. - Москва : Интермет Инжиниринг, 2002. - 496 с.

3. Smirnov S. V., Veretennikova I. A. Comparative Evaluation of Metal Damage on the Free Lateral Surface of Single-Layer and Three-Layer Strips under Rolling // Diagnostics, Resource and Mechanics of materials and structures. - 2015. - Iss. 4. - P. 6-15. - URL: http://dreamjournal.org/DREAM_Issue_4_2015_Smirnov_S.V._et_al._006_017.pdf

4. Kolesnikov A. G., Plokhikh A. I. A study of special features of formation of submicroand nanosize structure in multilayer materials by the method of hot rolling // Metal Science and Heat Treatment. - 2010. - Vol. 52, iss. 5-6. - P. 44-49. - DOI: 10.1007/s11041-010-9266-x

5. Трыков Ю. П., Гуревич Л. М., Шморгунов В. Г. Слоистые композиты на основе алюминия и его сплавов. - Москва : Металлургиздат, 2004. - 230 с.

6. Ложкин В. С., Ложкина Е.А., Мали В.И., Есиков М.А. Структура и механические свойства многослойного композита, сформированного сваркой взрывом тонколистовых сталей 12Х18Н10Т и Н18К9М5Т // Обработка металлов (технология, оборудование, инструменты). - 2014. - № 3 (64). - С. 28-36.

7. Мальцева Л. А., Тюшляева Д. С., Мальцева Т. В., Пастухов М. В., Ложкин Н. Н., Инякин Д. В., Маршук Л. А. Металлические слоистые композиционные материалы, полученные сваркой взрывом: структура, свойства, особенности строения переходной зоны // Деформация и разрушение материалов. - 2013. - № 4. - С. 19-26.

8. Embury J. D., Petch N. J., Wraith A. E., Wright W. S. The fracture of mild steel laminates // Transactions of the Metallurgical Society of AIME. - 1967. - Vol. 239. - P. 114-118. DOI: https://doi.org/10.1007/BF02661950

9. Ботвина Р. Л. Разрушение. Кинетика, механизмы, общие закономерности / Ин-т металлургии и материаловедения им. А. А. Байкова РАН. - М. : Наука. - 2008. - 334 с.

10. Ландау Л. Д. К проблеме турбулентности // Докл. АН СССР. - 1944. - Т. 44. - № 8. C. 339-342.

11. Cowan G. R., Bergmann O. R., Holtzman A. H. Mechanism of bond zone wave formation in explosion-clad metals. - 1971. - Vol. 2, no. 11. - P. 3145-3155. - DOI: https://doi.org/ /10.1134/S0036029514100073

12. Дерибас А. А. Физика упрочнения и сварка взрывом. - 2-е изд., доп. и перераб. Новосибирск : Наука, 1980. - 220 с.

13. Геометрические преобразования тонколистовых заготовок в процессе сварки взрывом многослойных пакетов / В. И. Мали, И. А. Батаев, А. А. Батаев, Д. В. Павлюкова, Е. А. Приходько, М. А. Есиков // Физическая мезомеханика. - 2011. - Т. 14, № 6. - С. 117-124. 
hittp://dream-journal.op"n

14. Лысак В. И., Кузьмин С. В. Создание композиционных материалов сваркой взрывом // Вестник Южного научного центра. - 2013. - Т. 9. - С. 64-69.

15. Перкас М. Д. Высокопрочноые мартенситно-стареющие стали. - М. : Металлургия. 1970. - $224 \mathrm{pp}$.

16. Gladkovsky S. V., Potapov A. I., Lepikhin S. V. Studying the deformation resistance of EP679 maraging steel // Diagnostics, Resource and Mechanics of Materials and Structures. - 2015. - Iss. 4. - P. 16-26. - URL: http://dream-journal.org/ /DREAM_Issue_4_2015_Gladkovskiy_S.V._et_al._018_028.pdf

17. Седых В. С., Соннов А. П., Шморгунов В. Г. Определение местной деформации при сварке взрывом // Известия вузов. Черная металлургия. - 1984. - № 11. - С. 136.

18. Мартин Дж. У. Микромеханизмы дисперсионного твердения сплавов / пер. с англ. М. : Металлургия, 1983. - 167 с. 